\title{
Urbanization and Sustainability of Artisanal Fishing Activities in Gaya Island Village, Kota Kinabalu, Sabah
}

\author{
Jalihah Md Shah ${ }^{1}$ \& Dzurizah Ibrahim ${ }^{2}$ \\ ${ }^{1}$ Sociology and Social Anthropology Programme \\ ${ }^{2}$ Industrial Relations Programme \\ Faculty of Humanities, Arts and Heritage, Universiti Malaysia Sabah \\ 1 $\underline{\text { jalihah@ums.edu.my }}, \underline{{ }^{2} \text { idzuri@ums.edu.my }}$
}

\begin{abstract}
Fishing activities are usually associated with rural based economic activities. However, studies in Gaya Island Village, Kota Kinabalu, Sabah found that fisheries also carried out by the urban community. Urbanization have created opportunities and dilemmas for fishermen in these villages. This ethnographic study is based on two objectives (i) to discuss the impact of urbanization on fishermen economic life; and (ii) to describe factors affecting the sustainability of fishing activities in urban areas. The study found that urbanization open opportunities to the involvement of non-fishery employment among the fishing households, increased education awareness, fishermen engaged in part-time jobs, urban wage-earner and fixed income as well as enjoying urban facilities. All of these provide income stability to the fishing household in Gaya Island Village but at the same time invokes the issue of uncertainties in fisheries economic activity through tourism development and conservation. The involvement of fishing households in the urban economy especially in the service sector has led to the questionable future of this activity. However, this study found that the nature of the fisheries sector is easy to access, government incentives and fishing skills are among the factors that can influence the sustainability of fisheries activities among the fishing community in Kota Kinabalu city.
\end{abstract}

\section{Keywords: Urbanization, Sustainability, Fishermen, Uncertainty, Gaya Island}

\section{INTRODUCTION}

The fishing community is constantly vulnerable to change and development in their environment. The development of the tourism sector and urbanization, for example, has not only provided employment to fishing households, but also had an impact on the fisheries activities of this community. The involvement of fishing household in non-fisheries economy can stabilize household income, but at the same time raise concerns about the continuity of fishing activities that inherited from previous generations. All these are challenges and dilemmas that must be faced by the fisheries household who live in urban areas, including the fishing community of Gaya Island Village, Kota Kinabalu, Sabah. Can these urban fishermen consisting of the Bajau, the Suluk and the Ubian ethnic groups continue to survive with their respective fishing activities 
or is this economic activity disappearing in the midst of the rapid development of the Kota Kinabalu City? Therefore, the discussion in this paper explains the impact of urbanization on the lives of fishermen and describes the factors that influence the resilience of fishing activities in urban areas.

\section{LITERATURE REVIEW}

Early studies pertaining to fishing communities in Malaysia was conducted by Raymond Firth, a famous anthropologist in the 1940s that conducted his study on Malay fishing village of Perupok, Kelantan (Firth, 1990). His comprehensive discussion of these fishing communities touch in detail the daily life of the Malays fishing activities, techniques and technologies used in fisheries and fishermen's relationship with middlemen as well as customs and taboos in these economic activities. All this according to Firth has affected the lives of Malay fishermen and this makes them live in poverty. In general, fishermen are individuals who engage in fishing activities in the sea area. According to Wan Hashim (1980), this activity is carried out full time and the individual goes to sea not less than 90 days a year. In Malaysia, the fishing community is also known as the coastal community (Nor Hayati, 2010; Ahmad Zubir \& Abd. Rahim, 2016) and the estuary community (Nor Hayati, 2017) which carries out fishing activities and collecting marine resources (Muhammad Wafi, Sharifah Rohayah \& Sofia Haminah, 2019) in Zone A which is 0-5 nautical miles from the beach. In addition, fishing activities are also carried out in the river (Jalihah, 2015; Mohd Lizal, 2020). According to Acheson (1981), the fishing community lives in an area in groups, settling by the sea or river and carrying out marine resource activities as the main source of income of the household.

Regardless of where the fishing community lives and these fishing activities are undertaken, they are often associated with poverty issues (Wan Hashim, 1980; Firth, 1990; Ishak, 1990; Nor Hayati, 2011; Jalihah, 2015; Muhammad Wafi, Sharifah Rohayah \& Sofia Haminah, 2019) and is often impressed with development and changes. The cause of poverty of this community according to Nik Hashim (1987) is closely related to the structure and work pattern of fishermen. In particular, poverty among fishermen is detailed by Nik Hashim due to (i) lack of capital to buy modern boats and equipments; (ii) low productivity; (iii) low level or reinvestment rate; (iv) partnership systems practiced in capture operations; (v) price systems that are detrimental to fishermen and (vi) seasonal fishing patterns. In other words, the structural factors of employment as a fisherman greatly affect the poor life of this group.

Earlier, Acheson (1981) mentioned that the uncertainty of physical and social environment has become one of the criteria in the fishing activities that fishermen have to face. Fish season and the weather are examples of physical environments that are directly related to fisheries that are beyond the control of fishermen. While competition with commercial fishermen, fisheries policy and the relationship between fishermen are examples of a social environment that can also not be controlled by fishermen. Both of this environment uncertainties can affect the income of fishermen. Nevertheless, development in the surrounding area of the fishing community also has a positive impact as well as challenges to their economic activities. Types of development that affect the social life and fishing activities are urbanization (Sudarmono, Junaenah \& Noor Rahamah, 2012), tourism (Haliza, 2011; Yahya, 2001) and conservation areas (Maipol, 2001). In general, urbanization have a diverse impact on the socio- 
economic life of the fishing community such as rising cost of living, competition for jobs and housing as well as access to modern facilities and technology (Samruzhaizad, Jamaluddin \& Azahan, 2014). Among the strategies that fishermen do to deal with income uncertainty is doing side work (McCay, 1978; Acheson, 1981). Clearly, the fishing community is a group prone to any changes that occur in their surrounding areas. They will struggle in order to ensure that income can be generated in their respective households.

\section{RESEARCH METHOD}

Ethnographic research of fishermen in Gaya Island Village of Kota Kinabalu, Sabah was collected using participatory observation techniques, in-depth interviews, document analysis, life history and diary writing. This study was conducted in three phases. The first phase of fieldwork in this community was operated from September 2012 until July 2013. During this phase, in-depth interview sessions were conducted with 54 full-time fishermen in Gaya Island Village. In addition, interviews were also conducted with the fisherman's children. For the purpose of collecting interview data, a set of interview questions containing key subthemes such as equipment used by fishermen, fishing skills and techniques were provided. Generally, the duration of the interview session lasts between one and a half to two hours recorded using an audio recorder. All these interview data are transcribed into document form and then analyzed according to the theme that has been set. Besides that, data were also obtained through participatory observations by followed a group of fishermen to the sea to observe the fishing activities carried out. After 2013, researchers returned to the field in year 2016 (second phase) and last time in August 2019 (third phase) to follow the development of this fishing community continuously. Interview sessions were conducted with the same respondents (10 people) around January to August 2019 and observations on the current situation of the group of fishermen involved. At this stage, the interview is more focused on the latest challenge issues faced by the respondents after year 2013 .

\section{FINDINGS AND DISCUSSION}

The urban environment can be advantageous and at the same time invite threats to fishermen's activities (Jalihah, 2017). In terms of benefits, fishermen in Gaya Island Village, which is the closest island to the capital of Sabah, has access to various infrastructure and services available in Kota Kinabalu City. Gaya Island was inhabited by a total of 10,328 people in 2013 with five settlements, namely, Lok Urai Village, Kesuapan Village, Pondo, Lok Malom and Gaya Island Village. Each of these villages has a population of fishermen while the majority of Malaysian fishermen live in Gaya Island Village. This village which is located about a 10minute boat ride from Kota Kinabalu city center gives fishermen the advantage to enjoy fish landing jetty facilities, ice supply, petrol and fish market as well as banking services. These various facilities directly help to launch the fishing activities of urban fishermen in Gaya Island compared to fishermen in rural areas of Sabah. Even this fishing villages that exist around the city have also opened up opportunities for fishermen's involvement in non-fishing economic activities (Ahmad Zubir \& Abd. Rahim, 2016).

Generally, fishermen in Gaya Island Village can be divided into six categories based on the type of equipment and techniques used for fishing. The six categories of fishermen are (i) cast net (selambau), (ii) outboard engines, (iii) pump boat, (iv) rowing, (v) jongkong and (vi) 
ships. Regardless of the category, all these fishermen have to compete with commercial fishermen who also do fishing activities around the same waters. One of the famous fishing locations among fishermen in Kota Kinabalu is Mengalun Island. Apart from that, fishermen in this area also share sea space with container vessels, miner and tourist boats. This is because the location for fishing is located between the stated water transport route areas. The sharing of sea space with other vessel indirectly threatens the safety of fishermen while at sea. Although the routine of fishing activities at sea is always vulnerable to danger, but the frequency of water transport that passes through the fishing location of fishermen has further increased the risk to the safety of fishermen. For example, there is a fishing boat that was once hit by a tourist boat and sank while fishermen fishing around the waters of Gaya Island Village.

The coastal areas that have been conserved since 1974 as well as the development of the tourism sector on Gaya Island have limited the fishing locations. As a result, fishermen had to do their fisheries activities in areas farther away from the environment where they live. This has directly increased the cost to sea such as petrol expenditure for the movement of fishermen to other locations. Unsafe housing such as the lack of legal ownership of houses and land makes the well-being of fishermen in Gaya Island Village faces threats. The status of urban fishermen who are also urban squatters resulted in the houses of fishermen in this area are likely to be demolished at any time. In fact, the proposal to relocate this fishing community to a new area on land residence could affect the livelihood of these community in the future.

Such threats do not take into account employment opportunities in the urban economic sector which also invites the issue of the sustainability of these traditional fishermen's economic activities in the future. The declaration of Kota Kinabalu as a city on 2 February 2000, has seen it grow rapidly. The capital of Sabah not only serves as an administrative center but also as a tourist attraction, locations of trade and industrial as well as educational hub (DBKK, 2011). The impact of the development of natural tourism in this city has made Gaya Island one of the five-star tourist locations. As a result, the island has always been the focus of tourism developers to set up resorts which resulted in the lives of the people on this island, especially fishermen are not guaranteed. For fishermen in Gaya Island Village, fisheries is preferred economic activity and inherited from their father. Although, this activities are often considered as a last resort occupation (Béné, 2003), however, the majority of respondents are involved in these economic activities of their own choice because they are interested in the marine environment itself. This is acknowledged by respondents aged between 40 years and above. They make fishermen as the sole occupation to support their families. In addition to interest, some respondents choose fishing as a source of livelihood because they do not have education, does not have other skills, easy to enter while providing direct and lucrative income during fish season.

The rapid urbanization in the Kota Kinabalu city provides various alternative employment opportunities beside from fishing activities to the residents of Gaya Island. This study found that there are concerns among respondents that their jobs are not inherited by the next generation. The increase in the number of shopping malls and the development of the tourism sector around the capital of Sabah has caused the children of respondents choose to work in the services sector. In addition to acquire fixed salary, the tourism sector provides an image of working in air conditioning rather than hot, rainy and tossed by the waves in the ocean as a fishermen. A study on 54 fishermen in Gaya Island Village found that a total of 15 
respondents had at least one household member involved in the hotel/resort sector or related. Although most of these children of fishermen working as subordinates in the hospitality sector, they are satisfied with the wages received. For these young people, even if they work as room cleaners, gardeners, boatman or waiters at hotels/resorts, they not only get a basic salary, but they are also given additional allowances. Hafiz, 21 year old, for example, receives a basic salary of RM500.00 per month and an additional allowance of RM150.00 for one point of his task. As a cleaner, he can earn an allowance of RM450 for three points within a month. Thus, a fisherman's son like Hafiz can earn RM950.00 a month for the work he does at the hotel. It is not surprising that some of the fishermen children left their jobs in fishing activities and joined the hospitality sector due to a more stable income factor. Even Hafiz himself, who had been making a living through fishing activities since he was 13 years old, quit fishing because he wanted a new work experience which he described as easier than being a fisherman.

Apart from the attraction of non-fishery economic activities, there is an awareness among fishermen of the importance of education for their children. Although past literature shows that the majority of fishermen have a low level of education (Muhammad Wafi, Sharifah Rohayah \& Sofia Haminah, 2019; Ali, 2013; Saat, 2010; Wan Mohd Zaifurin, Ibrahim \& Abdul Majid, 2009; Fadzilah, 2008; Ismail \& Mohammad Raduan, 2007), but research among the fishermen in Gaya Island Village has begun to emphasize the importance of education to their children. There are fishermen who penalize their children who do not want to go to school and there are even mothers who wait for their children until the daily school session ends. Apart from that, there are fishermen in this area who also encourage their children to find other jobs offered in the city center of Kota Kinabalu. The women, especially fishemen wives, are also less involved in the fisheries sector, as reported in previous studies (Narenderen, 1975; Md Shah, 1999; Majid Cooke, 2008). Young people and the wives who are more likely to engage in nonfishing jobs (Ahmad Zubir \& Abd. Rahim, 2016) become the savior of the family livelihood as acknowledged by the respondents 'my wife's income is used for kitchen expenses if I do not go to sea'. Thus, the regular monthly income received by the wives and children of fishermen involved in the urban economic sector is very significant to ensure the survival of the fishing household expenses, especially when they are not at sea either due to the monsoon season or fish season.

Working and receiving fixed income is a 'new form' of work done by members of the fishing household in Gaya Island Village which is different from their head of the family. The non-fisheries sector that is ventured into is hospitality either in the center of Kota Kinabalu City or a hotel operating on Gaya Island itself. The work done by the members of this fishing household are waiters, gardeners, cooks and boatman. The jobs mentioned are the choice of over 90.0 percent of the fishing household members studied due to low level of education. This clearly shows that there is a significant relationship between the low level of education and the rate of income received by the poor community (Siti Masayu Rosliah \& Narimah, 2018) including fishermen. Although the wages received by these fishermen's children still belong to the category of low income, however, it is still much better than the uncertain income of fishermen. In the meantime, since fishing activities are easily accessible economic activities (Béné, 2003), there are children of respondents who generate side income through these activities. The flexible time to engage in fishing activities has opened up opportunities and freedom for fishermen to generate income from other economic sources if they are not go to the 
sea. Thus, the nature of the work of these fishermen can be one of the contributing factors to the resilience of these economic activities in the households.

The hospitality sector is one of the options for the younger generation to leave the fisheries activities. However, this study also found young generation in Gaya Island Village inherited fishing from their father. In fact, some ventured into other jobs such as restaurant assistants and migrated to Kuala Lumpur by working as factory operators and finally decided to become fishermen again. The explanation for becoming a fisherman is driven by factors of work incompatibility and workplace environment, interest in fishermen's work as well as low educational factors. All these factors influence the selection of fishing household members making fisheries activities a source of income.

\section{CONCLUSION}

The urbanization has opened up new economic opportunities for fishing households and at the same time added uncertainty among the lives of fishermen in Gaya Island Village. Jobs as a fisherman in urban areas are likely to face sustainability issues in the future. This research shows 27.8 percent of the respondents household members are involved in non-fisheries economic activities. Even interviews with teenagers found that few wanted to be fishermen like their father. Therefore, households member that will continue fishing activities in the future are expected to decrease. Even so, the fishermen themselves see this urban as providing many benefits that further facilitate their fishing activities especially in terms of fish marketing, petrol and ice supply, fish landing center as well as access to urban infrastructure facilities such as banking. Although the income earned by fishermen is uncertain, however, this shortfall is offset by the income of other household members who earn a fixed income monthly by working in the services and tourism sector which is the economic driver of the city of Kota Kinabalu. On the one hand, the urbanization threatens the income of fishermen and the social security of fishermen's households, but at the same time it opens up job opportunities for fishermen and their household members. Employment arising from the rapid urbanization provides an opportunity for members of the fishing household and the fishermen themselves to further strengthen the uncertain source of their income.

This study found that 80 percent of fishermen will maintain their jobs. This is because the respondents have no other skills other than fishing. Another factor influencing this selection is the interest and income received directly and lucratively by the respondents after returning from the sea especially during fish season. There are also fishermen who return to fishing jobs because these activities are more flexible than work in other sectors. The nature of the fishing sector that is easy to venture into also allows fishermen to easily enter and exit without restrictions. Meanwhile, incentives given by the government in Malaysia such as Subsistence Allowance and e-declaration for fish catch can also be seen as an attraction for fishermen to continue to earn income in this sector. This study found a number of fishermen also took their children to the sea to provide early exposure to the work of fishermen. Although the number of respondent who do so is not large, at least the opportunity to pass on fishing activities to the next generation is still there. The resilience of fishing activities as a occupation of the population in urban areas is not an impossible one. However, issues surrounding fishing activities, especially poverty, need to be addressed in order to attract the younger generation to get involved and stay in this job. This study found that fishing activities have the potential to be defended if fishing activities are made as a family enterprise. In addition, fishermen can also 
venture into aquaculture. In Gaya Island Village, there is already a small group of fishermen carried out aquaculture such as crab, with a small scale i.e under their house. The variety of fishing activities can provide an alternative for fishermen to generate income in a controllable environment as opposed to going to the open sea.

\section{REFERENCES}

Ahmad Zubir Ibrahim \& Abd. Rahim Anuar. 2016. "Penentu Keterlibatan Nelayan Pesisir Pantai dalam Aktiviti Bukan Pertanian di Kuala Kedah, Kedah". Malaysian Journal of Society and Space (GEOGRAFIA). 12 Issues 14 (1-9).

Béné, C. 2003. "When Fishery Rhymes with Poverty: A First Step Beyond the Old Paradigm on Poverty in Small-Scale Fisheries". World Development Volume 31, Issue 6, June 2003, 949-975.

Fadzilah Majid Cooke. 2008. The Bajau of Mengkabong: Potential Partners in Wetlands Conservation?. Seminar Paper Series Number 5, 2008. Research Unit for Etnhography and Development, School of Social Sciences, Universiti Malaysia Sabah.

Ismail Ali. 2013. Nelayan Artisanal di Sabah. Kota Kinabalu: Penerbit Universiti Malaysia Sabah.

Ismail Ali \& Mohammad Raduan Bin Mohd. Ariff. 2007. "Hubungan Ekosistem Marin Pinggir Pantai dan Muara Sungai Dengan Sosio-Ekonomi Komuniti Nelayan di Teluk Brunei dan Teluk Padas, Sabah: Satu Tinjauan”. Jati, Vol. 12. December 2007, (229-245).

Jalihah Md Shah. 2017. "Keadaan Sosioekonomi Nelayan Bandar di Kg. Pulau Gaya, Kota Kinabalu, Sabah". LIFEWAYS - International Journal of Society, Development and Environment in the Developing World. Vol. 1, No. 2 (56-68).

Jalihah Md Shah. 2015. Nelayan dalam Bandar dan Pembangunan Komuniti di Kg. Pulau Gaya, Sabah. Tesis Ijazah Doktor Falsafah. Pusat Pengajian Sains Kemasyarakatan, Universiti Sains Malaysia.

Jalihah Md Shah. 1999. Wanita dalam Isi Rumah Nelayan: Satu Kajian kes di Kampung Weston Laut. Tesis Latihan Ilmiah, Program Sosiologi \& Antropologi Sosial, Sekolah Sains Sosial, Universiti Malaysia Sabah.

McCay, B. J. 1978. "Systems Ecology, People Ecology, and the Anthropology of Fishing Communities". Human Ecology, Vol. 6, No. 4, 397-422.

Mohd Lizal Jainuddin. 2020. Aktiviti Penangkapan Ikan dalam Komuniti Nelayan di Kampung Linayukan, Sugut, Beluran, Sabah. Latihan Ilmiah. Program Sosiologi dan Antropologi Sosial, Universiti Malaysia Sabah.

Muhammad Wafi Ramli, Sharifah Rohayah Sheikh Dawood \& Sofia Haminah Mohd Som. 2019. "Cabaran Hidup Miskin dalam kalangan Komuniti Nelayan di Tanjung Dawai, Kedah”. Malaysian Journal of Society and Space (GEOGRAFIA). 15 Issues 1, (54-66). 
Community: Volume 6, Nomor 2, Oktober 2020

p-ISSN: 2477-5746 e-ISSN: 2502-0544

Narendran Vasantha Malliha. 1975. The Women of Perupok: An Economic Study. Master of Social Science Dissertation. Universiti Sains Malaysia.

Nik Hashim Nik Mustapha. 1987. "Satu Analisis Ekonomi tentang Polisi Pembangunan Industri Perikanan dan Kesannya ke atas Nelayan dan Penggunaan Sumber". Dalam Mohd. Haflah Piei. Malaysia: Isu-isu Pembangunan. Bangi: Penerbit Universiti Kebangsaan Malaysia.

Nor Hayati Sa'at, Ibrahim Mamat \& Wan Mohd Zaifurin Wan Nawang. 2017. "Pola Perubahan Sosiobudaya dan Mobiliti Sosial dalam Kalangan Komuniti Muara di Pantai Timur, Semenanjung Malaysia”. Akademia, 87 (3), (163-176).

Nor Hayati Sa'at. 2010. Keluar Dari Lingkaran Kemiskinan: Mobiliti Sosial di Kalangan Komuniti Pesisir Pantai, Kuala Terengganu. Tesis Ijazah Doktor Falsafah, Kolej Undang-Undang, Kerajaan dan Pengajian Antarabangsa, Universiti Utara Malaysia.

Samruzhaizad Samian@ Samion, Jamaluddin Md. Jahi \& Azahan Awang. 2014. "Isu Perbandaran dan Kualiti Hidup Penduduk Pinggir Bandar". International Journal of the Malay World and Civilisation (Iman), 2 (1), (63-75).

Siti Masayu Rosliah Abdul Rashid \& Narimah Semat. (2018). Kemiskinan Keluarga dan Pengaruhnya Terhadap Tahap Pendidikan Rendah Masyarakat Luar Bandar: Kajian Kes di Jajahan Bachok, Kelantan. Journal of Social Sciences and Humanities (e-Bangi). Vol. 13, No. 2 (2018): 11-23.

Wan Hashim Wan Teh. 1980. Komuniti Nelayan di Pulau Pangkor: Beberapa Aspek Ekonomi dan Sosial. Kuala Lumpur: Dewan Bahasa dan Pustaka.

Wan Mohd Zaifurin Wan Nawang @ Wan Ahmad, Ibrahim Mamat \& Abdul Majid Mohd Isa. 2009. "Faktor Peramal Minat Belia Untuk Menjadi Nelayan: Satu Kajian di Mukim Kuala Besut, Terengganu”. Jurnal Teknologi, 50 (E) Jun 2009: 29-52. 